\title{
Effect of Site Specific Nutrient Management Approach In Productivity Of Spring Rice In Kanchanpur, Nepal
}

\author{
Chudamani Pant ${ }^{a *}$, Pankaj Prasad Joshib, Ram hari Gaire ${ }^{a}$, Binod Dahalc
}

a Department of Agronomy, Faculty of Agriculture Agriculture and Forestry University, Rampur, Chitwan.

b Asst. Prof. Department of Agronomy, College of Natural Resource Management, Tikapur, Agriculture and Forestry University

c Department of Horticulture, Faculty of Agriculture, Agriculture and Forestry University, Rampur, Chitwan

*Corresponding Author E-mail: pantchudamani@gmail.com

\section{Doi: 10.2478/mjhr-2020-0004}

\section{Abstract:}

A field experiment was carried out in sub-tropical climate of Bhimdattanagar, Kanchanpur to assess the effect of site specific nutrient management approach in productivity of spring rice. The experiment was carried in single factor randomized completely block design with four replication, in four different farmer's field, each farmers' field as single replication. The seedlings were grown in the mat nursery bed and transplanted in the experimental plots with different nutrient management practices. Nutrient management practices were Site Specific Nutrient Management with Nutrient Expert dose (SSNMNE)(109:28:38 kg NPK/ha), Government recommendation dose (100:30:30kg NPK/ha +6 ton FYM), Farmer's field practice (FFP)(different among farmers) with three omission plots viz. omission of Nitrogen (0:28:38 kg NPK/ha), Omission of Phosphorus (109:0:38 kg NPK/ha) and Omission of Potassium (109:28:0 kg NPK/ha). SSNM-NE dose was obtained by household survey in the respective area and using nutrient expert model. The growth parameters, yield, yield attributing traits and total cost of production were recorded. Data were analyzed using Duncan's Multiple Range Test (DMRT) in Genstat. Result indicates that the highest grain yield ( $5.81 \mathrm{t} / \mathrm{ha}$ ) was obtained from SSNM-NE which was statistically at par with government recommendation (5.54 t/ha). Similarly, thousand grains weight, straw yield in the experiment 23.20g, 6.90t/ha were significantly higher in SSNM-NE respectively. Straw yield, grain yield and thousand grain weight of SSNM-NE were found to be statistically at par with government recommendation. The economic analysis revealed that higher B: C ratio (1.91), net return and gross return were higher in SSNM-NE.

Keywords: Hardinath-1; Productivity; Nutrient Management; Phenology; Nutrient Expert

\subsection{Introduction:}

Rice (Oryza sativa L.) or Dhan in Nepali is an annual, self-pollinated and semi-aquatic plant of Poaceae Family. Rice occupies a significant position among the world's food crops. It accounts for $50 \%$ of total edible cereal production and about $20.75 \%$ to Agricultural Gross Domestic Product (AGDP) on the country and provides more than $40 \%$ of the total calories required to the Nepalese people [1,2]. In Nepal it is the most important cereal crop in terms of the total cultivated area, the food habits of the people, and the impact it has on the economy. In the fiscal year 2016/17, the rice was cultivated in the area of 1469423 ha with production of $5151925 \mathrm{mt}$ and productivity $3.50 \mathrm{t} / \mathrm{ha}$ [3]. The average productivity of rice in kanchanpur is $3.45 \mathrm{t} / \mathrm{ha}$ which is far less than the potential yield 9.08t/ha of Nepal [4]. Productivity is affected by amount, time, source and method of fertilizer application [5]. Blanket application of the fertilizer result in the over fertilize in some areas and under fertilize in others, or apply an improper balance of nutrient for their soil and also undesirable environmental effects such as nutrient mining or pollution of surface and ground water due to the variable indigenous nutrient supply NPK in different areas [6]. Further, the fertilizer use efficiency is also lower which ultimately reduces the production [7]. The fertilizer use efficiency of nitrogen is only 20-30\% in Asia; similarly potassium and phosphorous use efficiency are only 45\% and 20-30\% in world respectively. 75-80\% of potential yield can be obtained by proper nutrient management [8]. Nutrient management helps to reduce loss of fertilizer and increase the production and profitability in rice farming [9]. Identification of proper nutrient management practice is the foremost need to improve the production of rice and increase farm profitability in case of rice farmers [10]. Therefore, a new concept SSNM in rice based systems is being developed [11]. In SSNM approach, scientists quantify crop nutrient requirement based on an economically efficient yield target; measure the potential indigenous supply of $\mathrm{N}$, $\mathrm{P}$ and $\mathrm{K}$; estimate the $\mathrm{P}$ and $\mathrm{K}$ balance for sustaining soil $\mathrm{P}$ and K reserves without depletion; monitor plant $\mathrm{N}$ status during critical period of rice growth to optimized fertilizer N efficiency and apply diagnostic criteria for identifying micronutrient disorders [11]. The purpose of this study is to access the indigenous nutrient supplying capacity of the soil, the proper amount of the nutrient to be applied in the field to get proper yield and to change the attitude the farmer about the blanket application of fertilizer.

\subsection{Objectives}

\subsubsection{General Objective}

To assess the effect of site specific nutrient management approaches for enhancing productivity in spring rice in kanchanpur.

\subsubsection{Specific Objectives}

- To analyze the effect of different nutrient management on phenology of spring rice

- To analyze the effect of different nutrient management on yield and yield attributes of spring rice

- To analyze the effect of different nutrient management on economics of spring rice production

\subsection{Materials and methods}

2.1. Experimental site

The experiment was conducted in the farmers' plot of the Baghphanta and Ultakham village (represents terai) of Rice zone implementation site of PMAMP, Kanchanpur during the spring season of 2019. Its coordinates are 28ํ5'13” N latitude and Longitude 8019'16” E.

\subsection{Field layout and Treatments}

The experiment was conducted in the 4 farmer's field. Each farmer's field was considered as one Replication. The plot size of the field was of $2 * 4 \mathrm{~m} 2$. The experiment had the following treatments viz.

T1-Omission of $\mathrm{N}(0: 28: 38 \mathrm{~kg} \mathrm{NPK} / \mathrm{ha})$

T2-Omission of P (109:0:3838 kg NPK/ha)

T3-Omission of K (109:28:0 kg NPK/ha)

T4-Government recommendation (100:30:30 kg NPK/ha)

T5-Farmers practice (Different among farmers)

T6-Nutrient expert dose (109:28:38 kg NPK/ha) 
Composite soil sample were randomly taken from different using screw auger to record the initial soil physico-chemical properties of the experimental site. Soil $\mathrm{pH}$ that affects the availability of mineral nutrients varied from 6.0 to 7.3 with the average of 7.06 . The total carbon and nitrogen ranged from to $0.65 \%$ to $2.41 \%$ and $0.03 \%$ to $0.12 \%$ respectively with the average of 0.70 and 0.086 percent. Available P and Kalso varied greatly among the farmers' field. Soil texture varied among the field from sandy loam to Silt clay loam.

\subsection{Climatic condition during experimentation}

The monthly average rainfall of $1.08 \mathrm{~mm} /$ day was received during the entire period of experimentation. The highest rainfall was recorded during June (3.64 $\mathrm{mm} /$ day $)$ and minimum rainfall in a month of April $(0.16 \mathrm{~mm} /$ day) of crop growth period. The mean maximum temperature during the experimental period ranged from $34.060 \mathrm{C}$ to $44.380 \mathrm{C}$ during experimentation period. It was the highest during May and the lowest during February. Similarly, the mean minimum temperature during cropping period ranges from $16.770 \mathrm{C}$ to $29.210 \mathrm{C}$.

\subsection{Cultivation practices}

Mat nursery bed were prepared and Seed was treated with Salt water in the ratio 1:5(4kg common salt in 20 liters if water). Then the salt treated seed was cleaned with fresh water 2-3 times and the seed was dried. Seed was sown with seed rates of $100 \mathrm{gm} / \mathrm{m} 2$. The seedling was transplanted at the age of $25-$ 30 days with the spacing of $20 \mathrm{~cm} * 20 \mathrm{~cm}$ row to row and plant to plant distance at a depth of $2-3 \mathrm{~cm}$ with 2-3 seedlings per hill. The doses of fertilizers were applied as accordance to treatments. The pre-emergence herbicide Butachlor was applied by spray immediately after transplanting @2 kg a.i. in 400 lit of water for one hactare and two hand weeding were done in the plots to reduce the competition between the crops and weeds at 20 DAT and 45 DAT.

\subsection{Observation and measurement}

\subsubsection{Morphological observations}

Random sampling was followed for sampling plants on parameters like number of tillers and plant height in $\mathrm{cm}$. For sampling on further parameters, ten plants were randomly selected and tagged and data collections were made on the basis of morphological observation.

\subsubsection{Plant Height (Cm)}

The height of the main shoot of randomly selected sample plants was measured from the base of the plant to the tip of the longest leaf. After panicle emergence, height was measured from the base of the plant to the tip of the panicle or leaf, which ever was longest. The observations were recorded at 30 , 45, 60 and 75 DAT and at harvest.

\subsubsection{Number of tillers $/ \mathrm{m}^{2}$}

The counting of tillers/m2 was taken at each plot at 30, 45, 60 and 75 DAT then, average was worked out.

\subsubsection{Yield attributing characters}

\subsubsection{Number of grains per panicle}

Total number of grains from five randomly selected panicles was counted. Thereafter, mean number of grains per panicle was computed.

\subsubsection{Sterility percentage}

Total number of grains from five randomly selected panicles were separated and counted. Later filled and unfilled grains were counted manually. Thereafter mean filled and unfilled grains per panicle were computed and used to calculate sterility percentage.

\subsubsection{Test weight of grains (1000-grain weight)}

Grain samples were drawn randomly from the total produce of each net plot at the time of weighing and 1000 grains were counted manually. Thereafter, the weight of these grains was recorded on electronic balance and mean test weight was computed by dividing the total weight of 5000 grains with 10 .

\subsubsection{Yields}

\subsubsection{Grain yield $\mathrm{t} / \mathrm{ha}$}

After winnowing and cleaning, the grain yield obtained from each plot, were weighed on double pan balance. Later it was converted into grain yield $\mathrm{t} / \mathrm{ha}$ by multiplying with appropriate factor.

\subsection{Statistical analysis}

All the data from the experimentation were subjected to analysis of variance and Duncan's Multiple Range Test (DMRT) for mean separations. The software program, Microsoft word 2007 was used for word processing, Genstat program for running statistical analysis. The LSD values were calculated at 5\% level of significance.

\subsection{Result}

\subsection{Biometric observation}

\subsubsection{Plant height}

Plant height was significantly influenced by different Nutrient management practices. The mean plant height in the experiment varied from $36.05 \mathrm{~cm}$ at (30 DAT) to $89.77 \mathrm{~cm}$ at (75 DAT) (table-1). The nutrient levels were non-significant in 30 and 45 days after transplanting. Plant height was significantly influenced by nutrient levels at 60 and 75 days after transplanting. There At both the observation dates plant height of nutrient expert dose was significantly higher than nitrogen omitted plots. At 60 DAT, plant height of SSNM-NE dose was of rice was statistically similar $(65.13 \mathrm{~cm})$ with other nutrient level except nitrogen omitted plots $(55.93 \mathrm{~cm})$ whereas at 75 DAT, plant height of SSNM-NE plots $(89.77 \mathrm{~cm})$ were at par with farmer practice $(85.97 \mathrm{~cm})$ and significantly higher than government recommended dose $(83.15 \mathrm{~cm})$ and other nutrient omitted plots.

Table 1. Effect of different Nutrient doses on Plant height of rice in Kanchanpur, Nepal, 2019

\begin{tabular}{llllll} 
& \multicolumn{3}{c}{ Plant height $(\mathrm{cm})$} & & \\
\cline { 2 - 5 } Treatment & 30DAT $(\mathrm{cm})$ & 45DAT $(\mathrm{cm})$ & 60DAT $(\mathrm{cm})$ & 75DAT $(\mathrm{cm})$ \\
\hline Omission of Nitrogen & 36.05 & 46.82 & $55.93^{\mathrm{b}}$ & $77.72^{\mathrm{c}}$
\end{tabular}




\begin{tabular}{|c|c|c|c|c|}
\hline Omission of Phosphorus & 37.63 & 50.25 & $60.70^{\mathrm{ab}}$ & $80.30^{\mathrm{bc}}$ \\
\hline Omission of Potassium & 36.95 & 50.05 & $60.50^{\mathrm{ab}}$ & $82.70^{\mathrm{bc}}$ \\
\hline Nutrient Expert Dose & 38.73 & 52.90 & $65.13^{\mathrm{a}}$ & $89.77^{a}$ \\
\hline Government Recommendation & 38.83 & 50.47 & $60.65^{\mathrm{ab}}$ & $83.15^{\mathrm{bc}}$ \\
\hline Farmers Practice & 37.23 & 52.10 & $61.55^{\mathrm{ab}}$ & $85.97 \mathrm{ab}$ \\
\hline $\operatorname{SEM}( \pm)$ & 3.51 & 4.36 & 4.22 & 3.84 \\
\hline Mean & 37.49 & 50.43 & 60.74 & 83.27 \\
\hline LSD & Ns & Ns & 6.36 & 5.79 \\
\hline CV (\%) & 9.40 & 8.70 & 7.00 & 4.60 \\
\hline
\end{tabular}

Note: The treatment mean followed by common letters are not significantly differ from each other based on DMRT at $5 \%$ level of significance.

\subsubsection{Number of Tillers per square meter}

Numbers of Tillers per square meter was also influenced by Nutrient management practices (table: 2). The mean number of tillers per square meter varies from 226.3 (30 DAT) to 457.5 (75 DAT). The influence of different Nutrient management practice was not found to be significant in 30 DAT and 75 DAT and found to be significant at $45 \mathrm{DAT}$ and $60 \mathrm{DAT}$. The numbers of tillers per meter square were found to be significant at $45 \mathrm{DAT}$ and $60 \mathrm{DAT}$ with highest value of 662.50 and 622.50 respectively.

Table 2. Effect of nutrient doses on number of tillers per square meter in kanchanpur, Nepal, 2019

\begin{tabular}{|c|c|c|c|c|}
\hline \multirow[t]{2}{*}{ Treatment } & \multicolumn{4}{|c|}{ No. of Tillers per Sq. meter } \\
\hline & $30 \mathrm{DAT}$ & 45 DAT & 60 DAT & 75DAT \\
\hline Omission of Nitrogen & 226.20 & $386.20^{c}$ & $400^{\mathrm{b}}$ & 320 \\
\hline Omission of Phosphorus & 221.20 & $662.50^{\mathrm{a}}$ & $622.50^{\mathrm{a}}$ & 457.50 \\
\hline Omission of Potassium & 258.80 & $493.80^{\mathrm{abc}}$ & $472.50^{\mathrm{ab}}$ & 331.20 \\
\hline Nutrient Expert Dose & 278.80 & $598.80^{\mathrm{ab}}$ & $545.50^{\mathrm{ab}}$ & 442.50 \\
\hline $\begin{array}{l}\text { Government } \\
\text { Recommendation }\end{array}$ & 297.50 & $507.50^{\mathrm{abc}}$ & $486.20^{\mathrm{ab}}$ & 386.20 \\
\hline Farmers Practice & 216.20 & $463.80^{\mathrm{bc}}$ & $443.70^{\mathrm{b}}$ & 320.00 \\
\hline SEm & 40.40 & 53.10 & 51.30 & 44.40 \\
\hline $\operatorname{LSD}(0.05)$ & ns & $160.10^{*}$ & $154.60^{*}$ & ns \\
\hline $\mathrm{CV} \%$ & 17.90 & 20.50 & 20.70 & 23.60 \\
\hline P-value & 0.78 & 0.03 & 0.09 & 0.14 \\
\hline Grand mean & 249.80 & 519 & 495 & 376 \\
\hline
\end{tabular}

Note: The treatment mean followed by common letters are not significantly differ from each other based on DMRT at $5 \%$ level of significance.

\subsection{Yield attributes and crop yield}

\subsubsection{Number of grains per panicle}

Number of grains per panicle was influenced by nutrient management practices (table 6). Application of SSNM-NE had produced significantly higher grains per panicle (154.00) than other nutrient management practices but statistically at par with farmer's field practice (149.90) and government recommendation dose (148.40). The lowest number of grain per panicle was found in omission of nitrogen (128.10). 


\subsubsection{Sterility percentage}

Nutrient management practices had also significant effect on sterility percentage. Omission of phosphorus had significantly higher sterility percentage $(24.39 \%)$ but statistically at par with Omission of nitrogen $(24.29 \%)$ and omission of potassium $(21.94 \%)$. Lowest sterility percentage was found in SSNMNE (18.62\%).

\subsubsection{Thousand Grain weight}

Nutrient management practices had also significant effect on thousand grain weight (table 6). SSNM-NE plot had statistically higher thousand grain weight $(23.20 \mathrm{~g})$ but statistically at par with government recommendation $(23.00 \mathrm{~g})$. Lowest thousand grain weight was found in Omission of phosphorus $(21.93 \mathrm{~g})$.

\subsubsection{Grain yield}

Nutrient management practices had also significant effect on grain yield (table 7). Application of SSNM-NE had produced significantly higher grain yield. The grain yield of SSNM-NE (6.9 t/ha) was found to be statistically at par with government recommendation (5.546t/ha) and lowest grain yield was obtained in omission of Nitrogen (4.41t/ha).

\subsubsection{Straw yield}

Nutrient management practices had also significant effect on straw yield (table 7). SSNM-NE had produced significantly higher straw yield. The straw yield of SSNM-NE (6.900 t/ha) was statistically at par with government recommendation (6.652 t/ha) and farmer's field practice (6.395 t/ha).

\subsubsection{Harvest index}

Harvest index was found to be non-significant among all nutrient management practices. However numerically higher harvest index was found in omission of nitrogen.

Table 3. Effect of nutrient doses on yield attributes and yields in kanchanpur, Nepal, 2019

\begin{tabular}{|c|c|c|c|c|c|c|c|}
\hline & $\begin{array}{l}\text { No. of grain p } \\
\text { panicle }\end{array}$ & Sterility (\%) & TGW (g) & HI (\%) & & Straw yield ( $\mathrm{t} / \mathrm{ha})$ & $\begin{array}{r}\text { Yield at } 14 \% \\
\text { moisture(t/ha) }\end{array}$ \\
\hline Omission of Nitrogen & $128.10^{\mathrm{b}}$ & $24.39^{a}$ & $22.16^{\mathrm{c}}$ & 41.35 & & $5.09^{\mathrm{d}}$ & $4.61^{\mathrm{e}}$ \\
\hline Omission of Phosphorus & $152.70^{a}$ & $24.24^{\mathrm{a}}$ & $22.07^{c}$ & 41.08 & & $5.61^{\mathrm{cd}}$ & $5.02^{\mathrm{cd}}$ \\
\hline Omission of Potassium & $142.30^{\mathrm{ab}}$ & $21.94^{\mathrm{ab}}$ & $21.93^{c}$ & 40.29 & & $5.95^{\mathrm{bc}}$ & $4.98^{\mathrm{d}}$ \\
\hline Nutrient Expert Dose & $154.40^{\mathrm{a}}$ & $18.62^{\mathrm{b}}$ & $23.20^{\mathrm{a}}$ & 40.31 & & $6.90^{\mathrm{a}}$ & $5.81^{\mathrm{a}}$ \\
\hline Government Recommendation & $148.40^{\mathrm{a}}$ & $20.51^{\mathrm{b}}$ & $23.00^{\mathrm{ab}}$ & 40.40 & $\mathrm{a}$ & $6.56^{\mathrm{a}}$ & $5.54^{\mathrm{ab}}$ \\
\hline Farmers Practice & $149.90^{\mathrm{a}}$ & $20.41^{\mathrm{b}}$ & $22.65^{b}$ & 40.21 & & $6.39 \mathrm{ab}$ & $5.37 \mathrm{bc}$ \\
\hline SEm & 5.34 & 1.03 & 0.15 & 0.57 & & 0.17 & 0.11 \\
\hline $\operatorname{LSD}(0.05)$ & $16.08^{*}$ & NS & $0.45^{* * *}$ & NS & & $0.52^{* * *}$ & $0.35^{* * *}$ \\
\hline $\mathrm{CV} \%$ & 7.3 & 9.6 & 1.4 & 2.8 & & 5.7 & 4.5 \\
\hline P-value & 0.033 & 0.007 & $<0.001$ & 0.622 & & $<0.001$ & $<0.001$ \\
\hline Grand mean & 146.00 & 21.69 & 22.50 & 40.61 & & 6.08 & 5.26 \\
\hline
\end{tabular}

Note: The treatment mean followed by common letters are not significantly differ from each other based on DMRT at $5 \%$ level of significance.

\subsection{Economic analysis}

\subsubsection{Cost of production}

The cost of production was calculated for one hectare from the cost involved in the experimental plots. Production cost included general cost and treatment wise variable cost. The treatment variables were Urea, DAP, MOP, SSP, FYM and compost were included in the variable cost. The cost for watching birds after sowing and at maturity stage of crop was not included here because it is not needed in the farmer's field. The average production cost was about NRs. 75560. Among all the treatment, the highest production cost occurred in farmers field practice (NRs. 87060) followed by government recommendation (NRs. 84060), Nutrient expert dose (NRs. 73078.5), omission of phosphorus (NRs. 71075), omission of potassium (NRs. 70230) and omission of Nitrogen (NRs. 68023.5).

\subsubsection{Gross return}

Gross return was significantly influenced by nutrient management practice (Table 9). The average gross return in the experiment was NRs.125440/ha. Gross return for SSNM-NE was significantly higher than other management practices. Similarly, gross return in treatment 0 kg N/ha was significantly lowest (Rs. 11830) than other plots. SSNM-NE (NRs.139560) produced highest gross returns followed by government recommendation (NRs. 133110), FFP (NRs. 12880), 0 kg P/ha (NRs. 120510), 0 kg K/ha (NRs. 119730).

\subsubsection{Net return}

The average net return of the experiment was NRs.49850. and varied among the nutrient management practices. Net return for SSNM-NE was highest (NRs. 
66480) and the net returns of other nutrient management practices were statistically at par with each other (table 5).

\subsubsection{B: C ratio}

The average benefit cost ratio of the experiment was 1.667 and influenced by nutrient management. Among nutrient management practices, B: $\mathrm{C}$ ratio was highest (1.910) for SSNM-NE and B: C ratio of $0 \mathrm{~kg} \mathrm{~K} / \mathrm{ha} \mathrm{(1.705),} 0 \mathrm{~kg} \mathrm{P} / \mathrm{ha} \mathrm{(1.696)} \mathrm{and} 0 \mathrm{~kg} \mathrm{~K} / \mathrm{ha} \mathrm{(1.629)}$ were statistically at par with each other. The B: C ratio of government recommendation (1.584) and FFP (1.480) were statistically similar with each other.

Table 2. Total cost of cultivation, gross return, net return and B: C ratio of spring rice as influenced by Nutrient management practices.

\begin{tabular}{|c|c|c|c|c|}
\hline Treatment & $\begin{array}{l}\text { Total cost of cultivation } \\
\text { (NRs. ' } 000 / \text { ha) }\end{array}$ & $\begin{array}{l}\text { Gross return (NRs. } \\
{ }^{0} 000 / \mathrm{ha} \text { ) }\end{array}$ & $\begin{array}{l}\text { Net return (NRs. } \\
\text { ‘000/ha) }\end{array}$ & $\mathrm{B}: \mathrm{C}$ ratio \\
\hline Omission of Nitrogen & 68.02 & $110.83^{e}$ & $42.81^{b}$ & $1.62^{\mathrm{b}}$ \\
\hline Omission of Phosphorus & 71.07 & $120.51^{\mathrm{cd}}$ & $49.43^{b}$ & $1.69^{b}$ \\
\hline Omission of Potassium & 70.23 & $119.73^{\mathrm{d}}$ & $49.50^{\mathrm{b}}$ & $1.70^{\mathrm{b}}$ \\
\hline Nutrient Expert Dose & 73.78 & $139.56^{\mathrm{a}}$ & $66.48^{\mathrm{a}}$ & $1.91^{\mathrm{a}}$ \\
\hline Government Recommendation & 84.06 & $133.11^{\mathrm{ab}}$ & $49.05^{b}$ & $1.58^{\mathrm{bc}}$ \\
\hline Farmers Practice & 87.06 & $128.88^{\mathrm{bc}}$ & $41.82^{b}$ & $1.48^{\mathrm{c}}$ \\
\hline SEm & & 2.80 & 2.80 & 0.04 \\
\hline $\operatorname{LSD}(0.05)$ & & 8.45 & 8.46 & 0.13 \\
\hline CV\% & & 4.50 & 11.30 & 5.3 \\
\hline Grand mean & 7.556 & 125.44 & 49.85 & 1.66 \\
\hline
\end{tabular}

\subsection{Discussion}

\subsection{Plant height}

In the Nutrient expert plot the dose of nitrogen was higher than the other treatment. Nitrogen being major constituent of chlorophyll influences the photosynthetic activity of leaf and vegetative growth including plant height of the crop. The plant height in Nutrient expert dose was due to the balance application of fertilizers. The Nitrogen expert dose was with higher amount of Nitrogen as it enhanced the vegetative growth. The SSNM-NE is the recently developed precision nutrient management technology which assumes great significance in improving crop yields, restoring soil-fertility and enhancing nutrient use efficiencies with minimal deleterious effects on environment.

In current study, it was concluded that this software based nutrient management strategy out-yielded over the recommended blanket nutrient prescription $(100 \%$ RDF) [12]. Nitrogen is essential for rapid development in generative and vegetative growth and higher production which is controlled by all protein based metabolic processes [13]. Milkkelson mentioned that the leaves and stems contain a large portion of nitrogen taken up by the plant. Similar Result was obtained in the research carried out which reported that the balanced and high dose of NPK at specific site contribute to the plant height [14].

\subsection{Number of tillers per square meter}

The development of tiller primordia was found to be higher at high nitrogen levels [15]. Singh and Singh reported that increasing levels of nitrogen significantly increased total tillers per square meter up to a certain stage [16]. The nitrogen content was higher in SSNM-NE, so results in higher number of tillers per square meter. Uddin, Sattarand, \& Salam, reported that balanced and optimum use of fertilizer application increased the number of effective tiller. The application of $\mathrm{N}$ fertilizer may increase the number of productive tillers; however, not every tiller contributes similarly to high productivity $[17,18]$. The number of number of tillers per square meter of omission of Phosphorus but yield was not higher as the number and the size of panicles are closely related to the growth of tillers, although moderate tillering contributes greatly to rice yields, excessive tillering leads to high tiller abortion, poor grain setting, and small panicle size, and further reduces the grain yield [19]. The number of tillers increases upto 60 DAT and there after decreased till harvest. The decreased in number of tillers after flowering could be due to senescence of secondary tillers and tertiary tillers [20].

\subsection{Yield and yield attributing characters}

SSNM-NE and Government recommendation had produced significantly higher yield than Farmer's nutrient management practice implies the lack of nutrient input in farmer's practices. The lower yield in the farmer's management practice indicated that the farmer's yield can be increased by proper nutrient management. SSNM-NE works under the principle of SSNM and it is evident that nutrient dose provided by SSNM-NE fulfills the nutrient requirement of crop when required hence better grain yield, straw yield, thousand grain weight, effective tillers were [21,22].

\subsubsection{Number of grains per panicle}

The more number of grain per panicle in higher nitrogen rate(SSNM-NE) were probably due to better nitrogen status of plant during panicle growth period that was applied during second spilt dose of urea of NE recommendation. The availability of nitrogen in soil is essential for greater number of filled grains per panicle.

\subsubsection{Sterility}

The higher sterility percentage in was found on omission of phosphorus plot and minimum sterility percentage was found in SSNM-NE plot. It was found that necessary to know the optimum dose of phosphorus fertilizer to reduce spikelet sterility of rice, they reported that with increasing levels of soil fertility, the number of unfilled spikelet per panicle decreased with corresponding increase in filled spikelet. 
Higher thousand grain was observed in SSNM-NE plot. Test weight was higher if higher Nitrogen applied due to increase in chlorophyll content in leaves which lead to higher photosynthesis rate and ultimately plenty of photosynthesis available during grain development.

\subsubsection{Grain Yield}

The yield variability across sites was higher in the farmers' practices as compared to the NE treatment due to variable management of farmers. Other studies using NE for maize and wheat also showed significant yield advantage from the tool-based fertilizer recommendation as compared to existing practices [23]. A study also reported the same result that NE or SSNM practice showed the highest yield than the farmer practice [11]. There is significant increase in yield attributes with the increase in nitrogen levels [24]. A group researcher also confirmed similar result [9]. The SSNM-NE leads to enhancement in the growth attributes lead to photosynthates partitioning and better source-sink relationship, which enhance yield attributes. The leaf nitrogen content is directly related to chlorophyll content and depends on nitrogen uptake [24]. The nutrient management practices resulted significant differences in grain as well as in straw yields. On the other hand, imbalance nutrient applications in FFP probably the main reason for lower grain yield [25].

\subsubsection{Straw weight}

Straw yield is a function of vegetative growth. Balanced and optimum used of fertilizer (SSNM-NE) increased plant higher, green leaves/hill, tillers/hill and dry matter production which finally resulted in higher straw yield. Application of nitrogen enhances both photosynthetic activity and total above ground dry matter production [26-30].

\subsection{Economic analysis}

\subsubsection{Cost of production}

Farmer's field practice attributed to higher cost of production as compost manure was also used. Similarly, Government recommendation also results in higher cost of production due to the use of Farmyard manure.

\subsubsection{Gross return}

Gross return was higher in SSNM-NE due to higher grain and straw yield. The higher production of grains and straws results in higher gross returns.

\subsubsection{Net returns}

Net return was higher in SSNM-NE due to higher grain and straw yield (results higher gross return) and lower cost of production. Lower net return in FFP was due to lower grain and straw yield and higher cost of production.

\subsubsection{B: C ratio}

High gross return in SSNM-NE was due to higher gross return and lower cost of production as compared to Government recommendation and farmer's field practice.

\subsection{Conclusion}

The effect of different nutrient management in growth and yield of spring rice (Hardinath-1) was studied and the effect of crop establishment techniques on number of tillers $/ \mathrm{m} 2$, plant height, panicle length, thousand grain yield, grain yield and sterility $\%$ was assessed. Three averaged data across different dates of 15 days' interval suggested that SSNM-NE nutrient management technique exhibited highest average number of tillers/m2 (442.5), highest average thousand grain weight (23.20 gm), highest number of grain per panicle (154.40), highest grain yield (5.81 $\mathrm{t} / \mathrm{ha})$ and low sterility percentage (18.62\%) but was similar with government recommendation. Whereas, gross return, net return and B: C ratio was found higher in SSNM-NE. Although, yield and yield attributing characters were similar in both SSNM-NE and government recommendation, gross return, net return and B: C ratio was found higher in SSNMNE, So, SSNM-NE is suitable among different nutrient management practices for higher productivity and profitability under transplanted spring rice in kanchanpur district, Nepal.

\subsection{Acknowledgement}

The authors are thankful to Prime Minister Agriculture Modernization Project (PMAMP), Agriculture and Forestry University (AFU) and Rice Zone, Kanchanpur for the support provided for carrying out this research and for their co-operation.

\section{References}

[1] GON. "Rice varietal mapping in nepal: Implication for development and adoption. Government of Nepal: Ministry of Agriculture development, Depatment pf Agriculture, Crop development directiorate, 7, 2015.

[2] B. Basnet, "Envirinmental Friendly Technologies for Increasing Rice Productivity”, The Journal of Agriculture and Environment., Vol. 9, Pp. 34-40, 2008.

[3] MOALC, “Krishi Diary. Hariharbhawan”, Lalitpur: Nepal Government, 2016.

[4] A.P. Regmi, "Improving the productivity of rice-wheat system through field specific nutrient management in Nepal. Los Banos, Laguna, Phillippines", PhD dissertation submitted to University of Philippines at Los Banos (UPLB), 2003.

[5] M. Thapa, "Factors affecting fertilizer use efficiency in dry season paddy production in Makawanpur", Agronomy Journal of Nepal, (Agron JN), Vol. 1, Pp. 123-133, 2010.

[6] C. Adhikari, K.F. Bronson, G.M. Panuallah, A.P. Regmi, P.K. Saha, A. Dobermann, and E. Pasuquin, "On farm soil N supply and N nutrition in rice wheat system of Nepal and Bangladesh", Field crops Research, Vol. 60, Pp. 272-286, 1999.

[7] A. Ganeshamurthy, T., Radha, Nitrogen Management Paradigm in india. https://www.sciencedirect.com/topics/earth-and-planetary-sciences/nutrientuse-efficiency, 2017.

[8] C. Witt, A. Dobermann, S. Abdulrachman, H.C. Gines, G.H. Wang, R. Nagarajun, D.C. Olk, "Internal nutrient efficiencies in irrigated lowland rice of tropical and subtropical Asia", Field Crops Research, Vol. 63, Pp. 113-138, 1999.

[9] B. Singh, A. Pant, A. Bahtnagar, M. Bhatt, "Evaluation of Nutrient Expert Based Fertilizer Recommendation for Growth, Yield and Nutrient Uptake of Maize Hybrids and Soil Properties in Maize-Wheat Cropping System in Mollisol”, International Journal of Current Microbiology and Applied Sciences., Pp. 
3539-3550, 2017.

[10] S. Marahatta, "Increasing Productivity of an Intensive Rice Based System through Site Specific Nutrient Management in western terai of Nepal", The Journal of Agriculture and Environment, 2017.

[11] A. Dobermann, P.F. White, "Strategies for nutrient management in irrigated and rainfed lowland rice”, Nutrient. cyl. Agroeco Syst., Vol. 53, Pp. 1-18, 1999.

[12] V. Pooniya, S.L., Jat, A. Choudhary, A.K., Singh, C. Parihar, R. Ban, K.S. Rana, "Nutrient Expert assisted site-specific-nutrient-management: An alternative precision fertilization technology for maize-wheat cropping system in South-Asian Indo-Gangetic Plains" ICAR-Indian Agricultural Research Institute, Vol. 85(8), Pp. 996-1002, 2015.

[13] D. Lawlor, G. Cornic, "Photosynthetic carbon assimilation and associated metabolism in relation to water deficits in higher plants", Plant Cell Environment, 2002.

[14] S.S. Meena, "Effect of hybrid rice to nitrogen and potassium application in sandy clay loam soil”, Indian Journal of Agricultural science, Pp. 8-11, 2003.

[15] A. Tanaka, C. Garcia, "Studies of the relationship between tillering and nitrogen uptake of the rice plant. Soil Science and Plant Nutrition, 11, 3, 31-37, 1965.

[16] B. Singh, V. Singh, “Fertilizer Management in Rice”, Springer International Publishing AG, 2017.

[17] M. Budhar, S. Palaniappan, "Effect of integration of fertilizer and green manure nitrogen on yield attributes, nitrogen uptake and yield of lowland rice (Oryza sativa L.)", Journal of Agronomy and Crop Science, Vol. 176, pp. 183-187, 1996.

[18] K. Sahu, E. Kariali, P. Mohapatra, "Tiller dominance in rice is dependent on assimilate concentration of the panicle", Indian Journal of Plant Physiology, Vol (9), Pp. 402-406, 2004.

[19] W. Zhou, L. Tengfei, Z. Yang, T. Wang, F. Yong, Y. Chen, R. Wanjun, Morphophysiological mechanism of rice yield increase in response to optimized nitrogen management. Nature, 2017.

[20] S. Krishnakumar, S. Haefele, "Integrated nutrient management and LCC based nitrogen management on soil fertility and yield of rice", Scientific Research and Essays, Vol. 8(41), Pp. 2059-2067, 2013.

[21] T.M. Walker, "Hibrid rice response nitrogen fertilization for Midsouthern United states rice production", Agronomy Journal, Vol. 100, Pp. 381-386, 2008.

[22] N. Fageria., "Yield Physiology of rice”, Journal of plant nutrition, Vol. 30(6), Pp. 843-879, 2010.

[23] T. Satyanarayana, K. Majumdar, M. Pampolino, “A tool to optimize nutrient use and improve productivity of maize”, Better Crops., Vol. 97(1), Pp. 21$24,2012$.

[24] A.S. Bali, "Response of rice (oryza sativa L) genotypes to nitrogen level under Transplanted condition in kasmir valley", Indian Journal of Agronomy, Vol. 40(1), Pp. 59-69, 1995.

[25] S. Mehta, B. Seema, V. Kumar, "Performance of winter maize (Zea mays) hybrid to planting methods and nitrogen levels", Indian Journal of Agricultural Sciences, Vol. 81(1), Pp. 50-54, 2011.

[26] S.A. Dalling, "The physiological basis of Nitrogen redistribution during filling in cereals", American society of plant physiologists, Pp. 55-71, 1985.

[27] C. Witt, A. Dobermann, S. Abdulrachman, "Internal nutrient efficiencies of irrigated lowland rice in tropical and subtropical Asia”, Field Crops Research, Vol. 63(2), pp. 113-138, 1999.

[28] M. Thapa, "Factors affecting fertilizer use efficiency in dry season paddy production in Makawanpur", Agronomy Journal of Nepal, Agron JN , Vol. 1, 2010.

[29] C. Dobermann, A. Witt, "A Site-Specific Nutrient Management Approach for Irrigated, Lowland Rice in Asia", Better Crops International, Vol. 16, No. 1, 2002.

[30] P.J. Curran, "Exploring the relationship between reflectance red edge and chlorophyll content in slash pine", Tree physiology, Vol. 7(1-2-3-4), Pp. 33$38,1990$. 